\title{
ドラバル型速心分離器の性能についで
}

(クリーム分離機につんて)

\section{1. 错界}

比重差の小さい二液よりなる乳状液に遠心力利用し て喤・重二液に分离する装置として広く利用されている あのにドラボル型遠心分离機がある。この型の分离機の 分离板間㗂内に括ける二液の分离機構の計算については 著者の一人がすでに本誌***に報告したが，実際の運転 性能についてはいはげ発表された研究すきわめてすくな い。

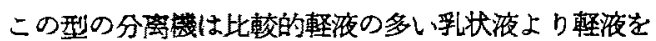
純粋に分离する8の，例完ば油清净機，之重液の多い乳 状液上り重液を純䊉に分离するもの，例えばクリーム分 离機，江種に分類される。

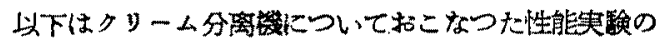
結果である。

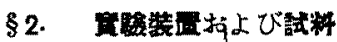

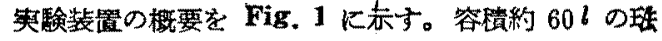

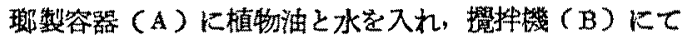

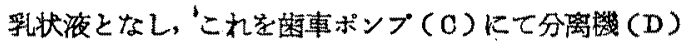
に供給循環せしめ，之の流量調節は分岥弁（E）にてお こなつた。

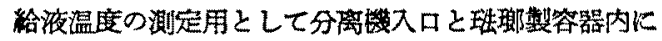

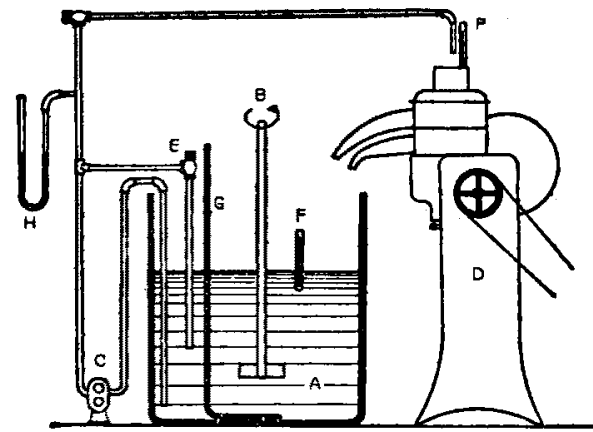
A : Reservoir.
C : Gear pump.
E: By-pass valve.
B : Agitator.
D : Separator.
G: Heater:
F : Thermometer.
Fig. 1
H : Manometer.

*炤年 26 年 5 月 12 日受理 科研大山研究空轺告第 14 号

** 東意工来大学 *** 科学研究所 大山研究案

***化学和, Vol.14, No. 3, 90 (1950)

$$
\text { 大山義年**.井上一郎*** }
$$

温度計 $(F)$ 括き, 签器内には温度調節用に容量 $1 \mathrm{~kW}$ の電熱器 (G) を入れた。

本実験に使用した分离機は牛乳分离用のもので，回転 数 8,850 r.p.m., 呼称容量 $180 \mathrm{l} / \mathrm{hr}$ で㐫るが，本実験に 污いてては回忶数 9,100 r.p.m., 給液流量は約 $60 \sim 270 \mathrm{l} / \mathrm{hr}$ の範囲にわたりおこなつた。

分窝機回転体招よびその附属装置の構造を Fig. 2 に 示す。軽液吐出量の調節は Fig. 3 (a)のごとく，水取 板の上部にある正方形状吐出口の上に正方形状調節板を 拓き，その位置穴回転して調節する。本実験に括いては 中心定通る対角線の最小の場合と調節板を外した最大の

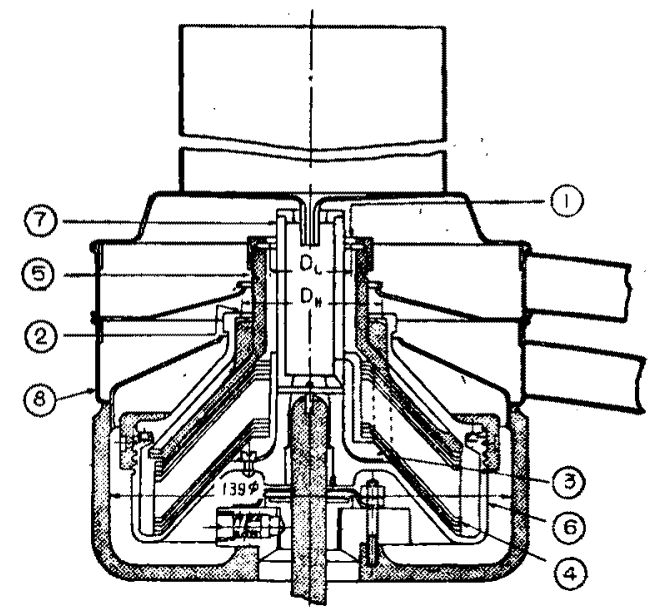

1 : Discharge lip for Highter liquid.

2: Discharge lip for heavier liquid.

3: Feed hole.

4: Separating disc.

5: Top disc.

6: Bowl.

7 : Guid pipe.

8: Cover.

Fig. 2
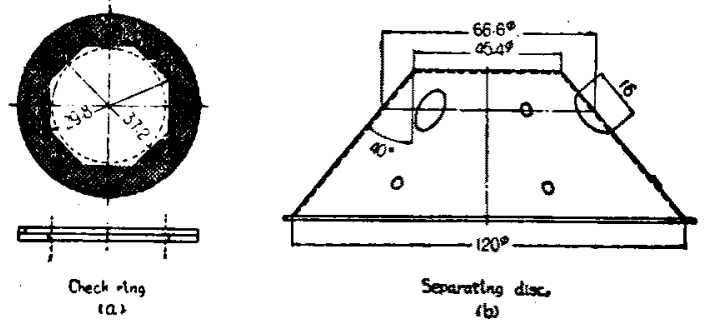

Fig. 3 
場合にておこない，その値はそれぞれ29.8；37.2 mm であつた。以下これらを以て代表直径と寺る。

他方，重液吐出口には円形堤をなす直径 48，50，53， 55，57 mm なる調節板を使用した。

分离板は Fig. 3 (b) のごとく半頂角 $40^{\circ}$ なる円雓形 状のるので，給液用の3個の棈円形の孔を有す。分离板 には間吵保持のため9個の円形状閒隍保持片か溶接され， その平均間隔は $0.498 \mathrm{~mm}$ で，その誤差は $4.8 \%$ であつ た。(他のクリーム分离機の例 : 平均間隔 $0.604 \mathrm{~mm}$,

誤差 9.4\%）また，分离板の表面は錫渡金され，合計 20 枚使用した。

実鈳試料には五蜀㯟，落花生，大豆の三種の植物油を 用いっこれらを文れぞれ水に加えて乳状液とし，落花生， 大豆油による乳状液の場合には少量の苛性ソーダを加え た。

こふに使用した植物油の比重は

玉蜀㯟油 : $0.910\left(25^{\circ} \mathrm{C}\right)$

落花生油 : $0.873\left(12.5^{\circ} \mathrm{C}\right)$

大豆油: $0.930\left(25^{\circ} \mathrm{O}\right)$

にして，各乳状液中の油の含有率は

玉罚系学狀液 : 7.5 vol. \%

落花生乳狀液： 7.1 vol.\%

大豆乳狀液： $8.0 \mathrm{vol} . \%$

であつた。

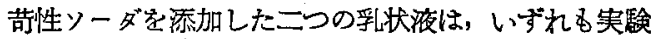
用遠心洗澱機によるか，あるいは長時間静置して乳状液 を分离して後観察すると,これらは油，クリーム状物質， 水の三層にわかれ，あたかる三成分のごとき状熊を呈し た。このクリーム状物筫は醶化物で水と油の中間に層を なし，㝋の比重は落花生乳状液の場合は $0.9496\left(25^{\circ} \mathrm{O}\right)$, 大豆乳状液の場合は $0.9630\left(25^{\circ} \mathrm{C}\right)$ で西つた。五蜀雿 乳状液はクリーム状物䓄の存在せぬ二成分の状熊にあ た。

なお，上記の油含有率の測定は塩折法によりェーテル に抽出せしめて油量を測定し，実験前後の值の平均にて 示した。

\section{§3. 實 驗 摡 要}

本実験は次の三つよりなる。

[I] 通水実験，士なわち，種々の温度の水のみを給 液した場合の軽・重液偩吐出流量の测定 (一成分采)。

[II]. 孚状液老使用して重液吐出口の調節板变变えた 場合の整・重吐出流量の測定 (二成分系)。

[DII] 乳状液中のクリーム状物質の分离板上への附 着現象家主とする観察ならびに給液流量,吐出流量、吐出 波の比重等の測定 (三成分系)。
給液流聂上昍出流量の測定は定常運転の後,メスシリ ンダーと秒時計にて測り，給液流量は軽・重吐出流量の 和と直接测定とより平均して承めた。

比重の測定は落花生乳状液の場合には浮秆比重計にて 大豆乳状液の場合には比重瓶にて測定した。また，これ らの吐出液中には微少の気泡岌含むのでその排出に充分 意を用いた。

クリーム状物質志含む乳状液にて定常通転した後，回 転体をとめて分解すると分离板上に後述するごとくきわ めて明膫な境界安持つてクリーム状物質が带状に附着す るのでこの境界線の位置の測定を括こなつた。

\section{\$4. 酉駐結果とその檢討}

\section{[I]一成分系}

一定温度の水を分离機に給液した時軽・重吐出口より の吐出流量は Fig. 4(a)，(b) の一例に示すがごとき関 係となり，図よりあきらかなごとく，給液流量Qの少ない 間は重液側吐出流量 $H$ のみで軽液側吐出流量 $L$ は全く なく，ある給液流量以上になると軽液側よりる吐出する ことが認められた。

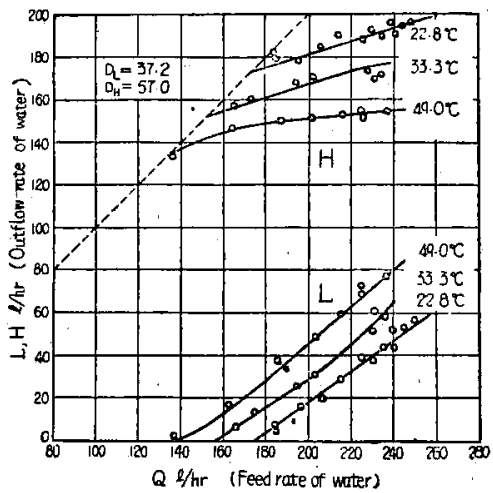

(a)

(a) -

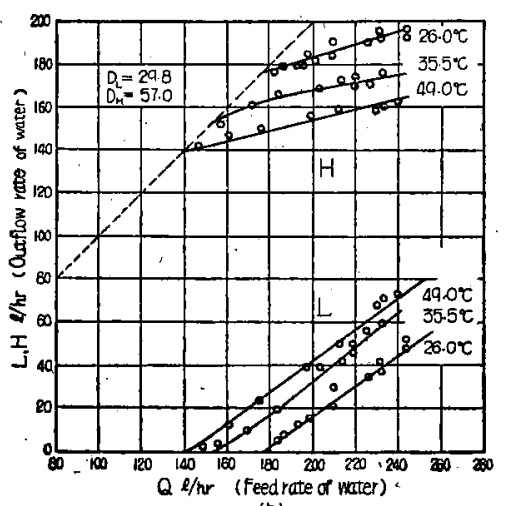

Fig. 4 (b) 
この軽液側より将に吐出せんとするときの液給流量， すなおち，重淮側吐出流量を臨界吐出流量 $Q C$ と名付け， 図上りこれを求めて水温 $t$ との関係にて示をとFig.万の ごとくになりこれより次のことが知れる。

（1）温度一定なるときは，整液側調節板代表直径 $D_{L}$ が小さいと臨界吐出流量は大きく, 代表直径が大きいと 臨界吐出流量は小さい。

（2）埾液側調節板代表淔径が一定なるときは，水温 の上舁によつて臨界吐出流量は減少する。

(1)の現象の原因は重液側より吐出せしめる推進力, す 'なおち, 重液側液面と毦液側液面との間の遠心力にて生 ずる流体圧力と考えられるから，軽液側調節板代表直径 が小さいと推進力が大きくなり臨界吐出流甼が增加し， また，代裁直径が大きくなると推進力が小さくなり臨界 吐出流最が減年ると解される。

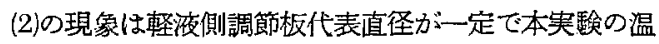
度範囲では比重が殆んど一定であるから，推進力る不变 そ見做され，したがつて回忶体内に生ずる流動抵抗によ るるのと考えられる。

Fig. 6 汇臨界吐出流量とその温度における水の粘性 保数 $\mu$ との関係走す。これによれば粘性の減少にした がつて流動抵抗が增加し臨界吐出流量が減少したことに はり，一見矛盾のごをくみえるが次のごとく考えること により理解されよう。

すなうち，分雜板間㗂内について供給液は給液孔より 半徍方向の流れを伴いながら分離板の角速度より遅れる

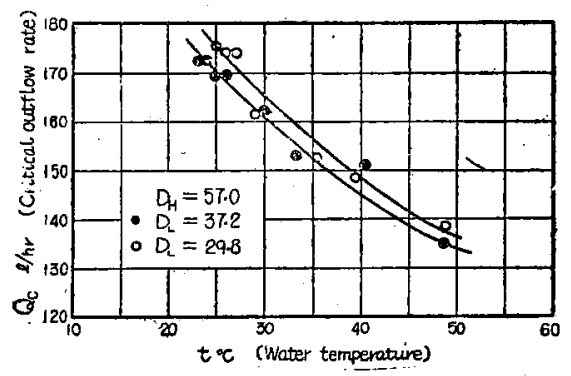

$<$ Fig. 5

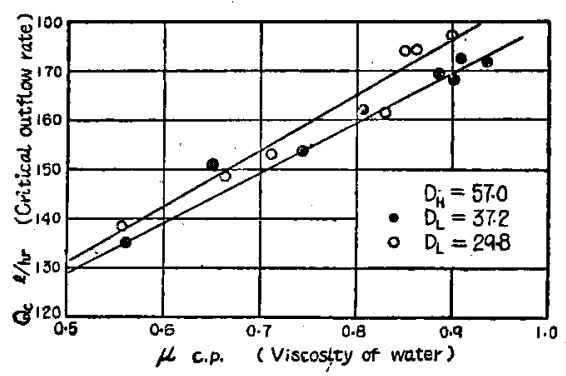

Fig.
滑りを生でここの滑り速度は粘性の減少につれて堌大す る。このため，分雕板間吵内の相対流動速度が大きくな り流郋低抗老をして軽液側上りの吐出客易にする。

油のみを給液した場合む括こなつたが，重液側のみ吐 出し軽液側よりは吐出せしぬることはできなかつた。 そ，分㒕板の棈指の差翼についての実鈳は改めて報告す る。な括，重液測調節板直径 $D_{U}$ は $57 \mathrm{~mm}$ のものを使 用した。

\section{[II] 三成分系}

王蜀霡油定使用した乳状液定用いて軽液側調節板代表 直径 $D_{L}$ を $37.2 \mathrm{~mm}$ とし, 重液側調節板直径 $D_{B}$ を

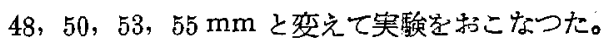

調節板值径空变え $25^{\circ} \mathrm{C}$ の玉凅雪乳状液を供給した场 合の㪕・重吐出量 $L, H$ 間の特性を一括して Fig. 7 K 示す。

これから軽・重昍出流昷間には給夜流量の゙範囲によつ てこつの部分にわけて哮えことができる。すなわち， 吐出流量の少ない部分の直線と吐出流量の多、部分の直 線である。この二直線の交点は調節板直俓の大きい洼ど 給液流量が多く，この交点以上の䉇围では案内筒より供 給液が一部溢流して吐出軽液中に混入することをみとめ た。よつて分離機としてはこの交点以下て使用されるべ きで，本実験に使用した分济機では調節板直径に応じて $80,105,145,170 l / \mathrm{hr}$ の給夜流量で乎称容量の 94.5 , 80.5，58.4，50\%にあたる。

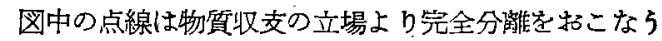

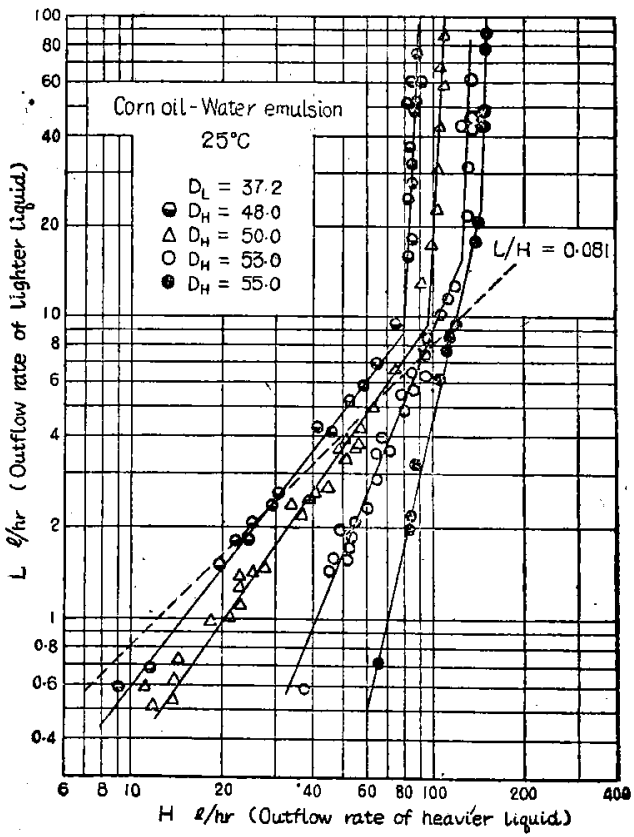

Fig. 7 
必要条件を示守基準直線で

$$
\frac{L}{H}=G(=0.081)
$$

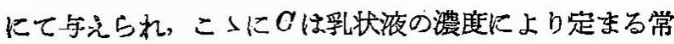
数である。

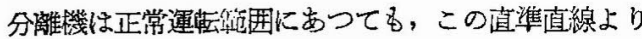
検討して次のことがいえる。すなわち，この基準直線よ り上の領域では时出西液は純粋状態で，吐出许液は混合 状態で西り，また，下の頒域では吐出軽夜は純粋状態で， 叶出重液は混合状態である。これは寒䛢的にもほよ゙確め 得た。

よつてクリーム分離機の立場よりすると基準直線より 上の領域に流最特性がなければならぬが，か子る組成の

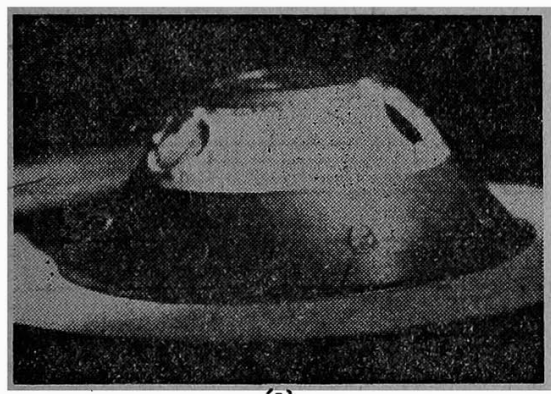

(a)

Peanut oil-water emulsion. $Q=2131 / \mathrm{hr}, \quad D=80 \mathrm{~mm}$.

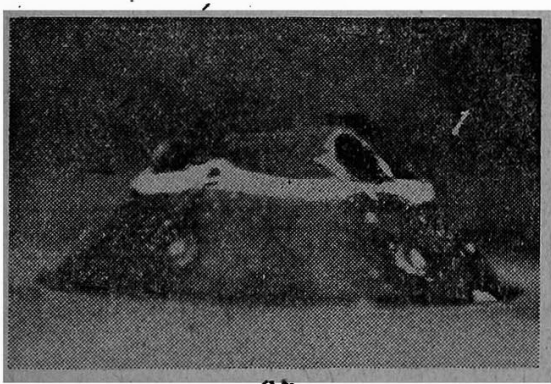

(b)

Soybean oil-water emuksion. $Q=2241 / \mathrm{hr}, \quad D=80 \mathrm{~mm}$.

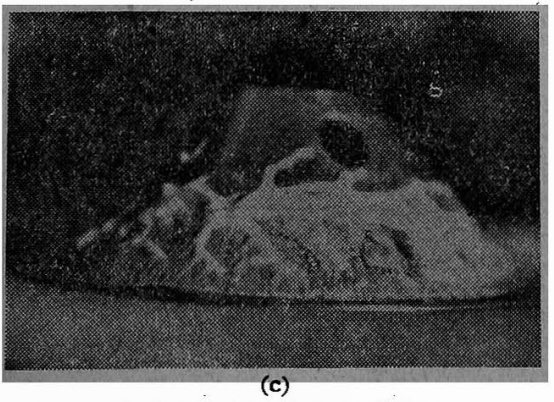

Soybean oil-water emulsion. $Q=145 \mathrm{l} / \mathrm{hr}, \quad D=120 \mathrm{~mm}$.
乳状液より軽液を純粋に採る必要のある場合には基淮直 線より下の領域に流量特性を扎くべきである。

給液流量の少儿所より二直線の交点, すなわち, 許容 鼠大給液流昷迄の流量特性は次の関係式で与兄られる。

$$
L=a H^{b}
$$

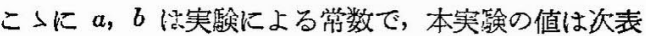
のごとくである。

\begin{tabular}{ccc}
$D_{f} \mathrm{~mm}$ & $a$ & $b$ \\
\hdashline 55 & $3.57 \times 10^{-7}$ & 4.47 \\
53 & $1.11 \times 10^{-4}$ & 2.45 \\
50 & $1.30 \times 10^{-2}$ & 1.44 \\
48 & $3.03 \times 10^{-2}$ & 1.29
\end{tabular}

bは完全分離堂抢こ なう場合には1でなけ ればなら收。またっりり 一ム分踓機としての運

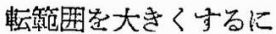
は，(1)，(2式の交点老 給液流量の少ない位置 にくるように調節板直 俓を選定すべきで, こ れは $a$ を大きくなるこ とを意味する。

(2式と物質収支の関 媇とを結びつけると給 液流量に上る吐出液の 比重変化の概要学す知 ることができる。

[III]三成分巢

落花生扣よび大豆乳 状液を用いた寒験に括 いては，写真特よび

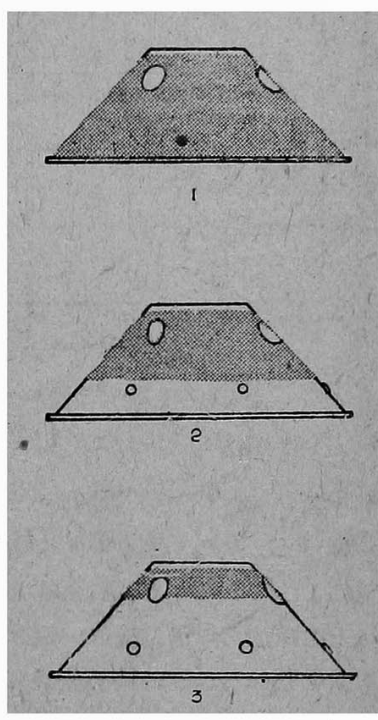

Adhered figures of cream-like matter.

1. Small feed rate.

2. Intermittent feed rate.

3. Large feed rate. Fig. 8
Fig. 8 のごとく中閒比重のクリーム状物質がいずれの 分離板上にも帶狀定なして附着し, 带の上下とる明膫な 境界を示すことが認められた。

この上部境界線は給液流量 $Q$ に，また，試料にもよ らずほとんぞ一定の位置に附着して，この位置は本実験 の重液側調節板值俓 $D_{H}$ すなわち，57 $\mathrm{mm}$ に等しいこ とを磪めた。

この附着帯の上部境界線泭近の成分はほとんど油より なり，下部境界線の方向に向うにしたがつてクリーム状 物筫が多くなり，下部境界線では汪とんどクリーム状物 質のみとなる。

下部境界線は給液流量の变化によつて，附着位置安異 


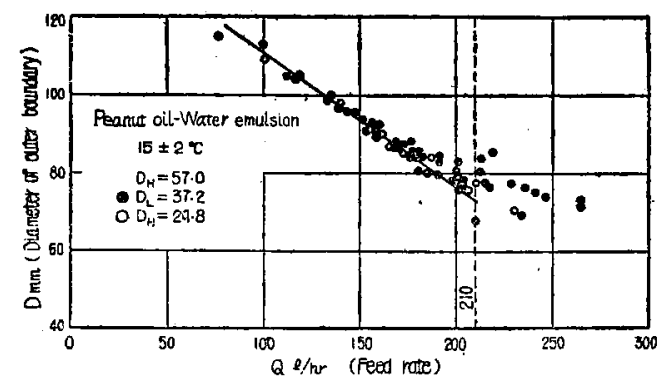

Fig. 9 (a)

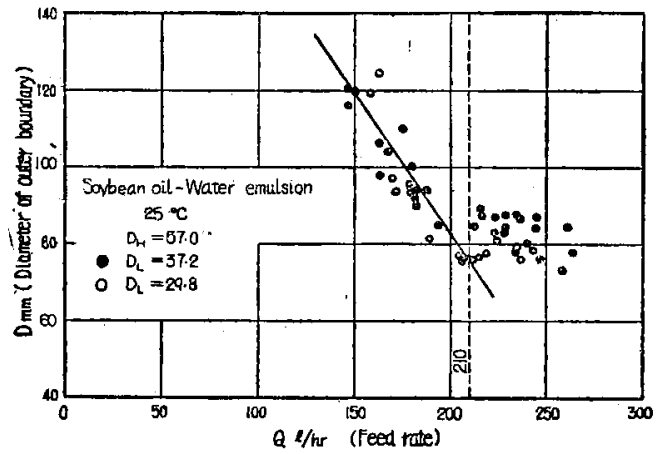

Fig. 9 (b)

にする。この下部境界線直巠 $D$ と給液流量との関俰を Fig. 9 に示す。図よりあきらかなごとく給液流量の増 加によつて下部境界線は減少し, 給液流量が䄪 $210 l / h r$ 以上になると附着位置は一定な関係学有しない状態とな る。すなわち，この給液流量は音項 [II] の笑験の交點 に相当する值で，本実験に括いても案内筒より溢流する ことが認められた。

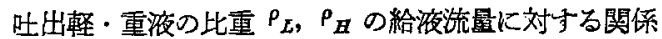
は Fig. 10 のごとくである。Fig. 10（a)，(b)は落花、 生, 大豆乳状液安使用した吐出僌液比重の变化を示す。 吐出重液の比重は落花生乳状液を用いた場合には給液流 易によりほとんど变化宗さざ， $\rho_{B} \doteqdot 1$ であつた。それ に対し大豆乳状液の場合には Fig. 10 (c) のごとき関倸 を得た。

この結果によれば，吐出冓液の比重は給液洗量の少小 時は供給乳状液の比重に近く，給液流量が堌すにつれて 水の比重に近くなり，更に增すと再び比重が減少する。

すなわち, 給液流量の少ない所では Fig. 8 に示した ごとく帯状のゆが非常に広くて，时出重液中にクリーム 状物質が件われがちのためと解される。

給液流量の多いときは回転体の回転によつて軽・重吐 出口附近に気流運動を生じ, 吐出軽液が吐出重液に混入

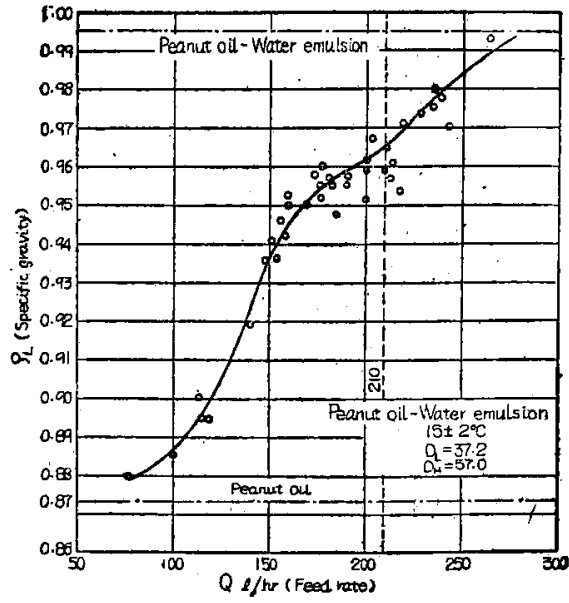

Fig. 10 (a)

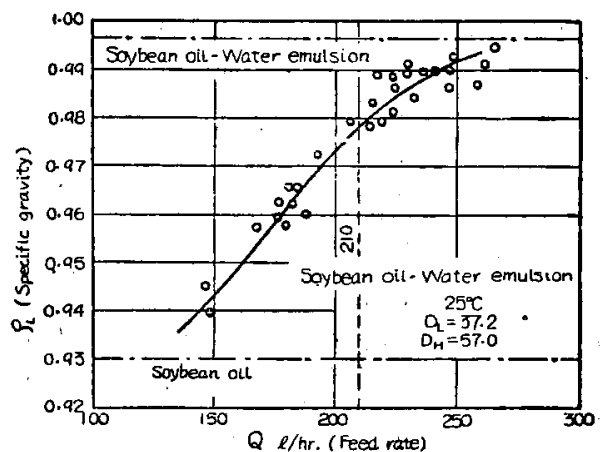

Fig. 10 (b)

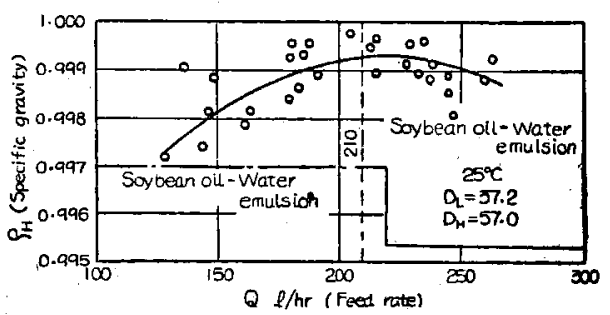

Fig. 10 (c)

ナるための比重の減少と推定されるが，この闍題につい ては目下研究中であらためて報告する。これよりして分

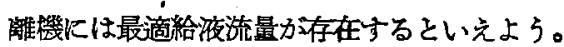

こ১でクリーム状物棸の附着帯の生成機構について考 察する。一般にドラバル型分離機の回転体内に軽・重比 重の二液力゙遠心力の作用の下に一定境界面にて釣合つて いるとき，

$$
P_{L}\left(D_{n}^{2}-D_{L}^{2}\right)=P_{H}\left(D_{n}^{2}-D_{H}{ }^{2}\right)
$$


が成立するとされている。こつに $D_{n}$ は平衛境界面の直 徑である。実際については潧度勾配, 滑り等を有してい ると考兄られるから一般の乳状液の連続分離をむこなう ときには当然このような簡単な関倸は適用されない。

仮に(2)式の閣係上り水と純粋な落花生油と大豆油につ いて平衡境界面淔径堂求めてみると次表のごとくなる。

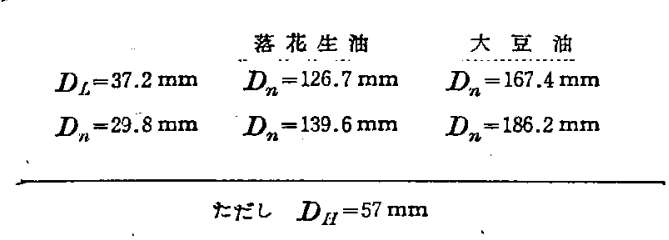

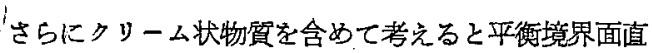
径の值はさらに大きくなり，上記のごとき計算が適用さ れるとしてあ構造上分離板外径 $128 \mathrm{~mm}$ のため，この 境界面は分離板外にあることとなろう。いま，この面を 仮想境界面と呼ぶことにする。

給液流昷が非常に少ない場合には回分操作条件に近つ くから仮想境界面の存在艺考光ても大過ないといえよ ら。したがつて下部境界線直径の大きくなることが納得 される。

Fig.9よりあきらかなごとく，クリーム状物質の附着 帶が分離板全面に附着した場合 $(D \doteqdot 120 \mathrm{~mm})$, 落花生 乳状液と大豆乳状液とでおのおの給夜流量を異にする原 因も仮想境界面の直径の值が異な西ためと考㝋られる。

給液流量の增加にしたがつて次第に下部境界線直径の 娍少するのは次のごとく説明される。前項 [II] に述べ たごとくこの場合も重液側は純粋状態で, 軽液側は混合 状態にある。これは回転体内に括いて流体の䯚りその他 による復乱作用を生じ，これか軽液側の分離度の低下と

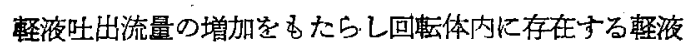
成分の量が減じて境界面直径がささくなる。

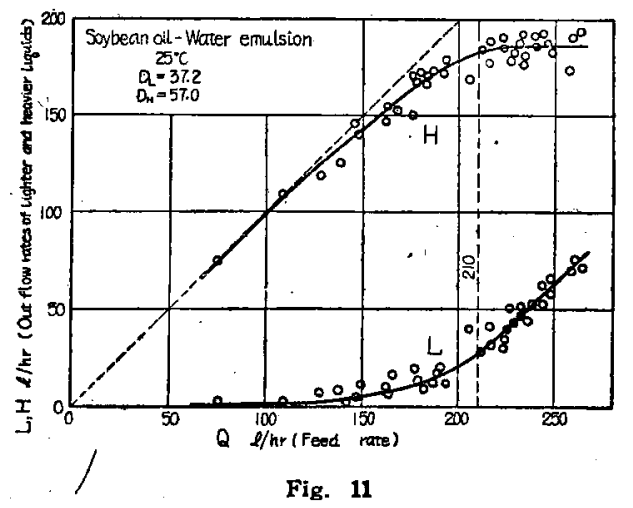

第16 巻 第 1 号 (1952)
Fig. 11 は本実験の一部で, 給液流量と軽・重吐出流 量間 $L, H$ との関係省す。

本実験の落花生乳状液招よび大豆乳状液の給液温度は

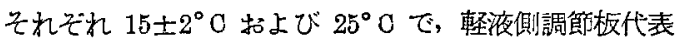
直径は $37.2,29.8 \mathrm{~mm}$ で重液側調節板直径は $57 \mathrm{~mm}$ を使用した。

\section{§5. 結 言}

以上クリーム分晟機の性能について考察した結果を總 括すると次のごとくである。

（1）二成分系乳状液を使用与る場合の㪕・重吐出流量 間炕は $L=a H^{b}$

なる関保分成立する。

（2）油，水，瞼化物上りなる三成分系の乳状液の場合 には, 分離板上に明膫な带状崖なして中間比重の羷化物 が泭着し，その附着带の巾は給液流量に上り異なる。

（3）与兄られた分離機の分離能性能にかんしては，給 液流量分支配的に作用し，また，最適給液流量がある。

（1）クリーム分離譏としては，'操作可能範团内で軽液 側調節板の径は大きく, 重液側調節板の径は小さいこと が望ましい。また，軽液を純䊉に得る目的のためには重 液側調節板の径は大きくすべきである。

（5）分離機に括ける液の流動には回転体に対して円周 方向の滑りを伴う。分離度は液の粘性の小さい程良好で あると一般にいわれているが，粘性が小さいと上述の滑 り量が增して；これが分離度变低下させる傾向を与える と考えられるので，粘性交充分考慮すべきである。

附記 本研究に協力された星野㢈治氏ならびに種々助

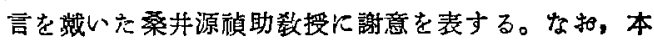
研究の一部は文部省試驗研究賓によった。

\section{使用钎号}

\begin{tabular}{|c|c|c|}
\hline$D:$ & ：附着帶下部境界線㨁经 & {$[\mathrm{mm}]$} \\
\hline$D_{H}:$ & ：重液側調節板直坴 & {$[\mathrm{mml}]$} \\
\hline$D_{L}$ & ： 軽液側調節板代表㨁径 & {$[\mathrm{mm}]$} \\
\hline$D_{n}$ & ：本男境界面直径 & {$[\mathrm{mm}]$} \\
\hline$H$ & ：重液 (側) 吐出流量 & {$[\mathrm{l} / \mathrm{hr}]$} \\
\hline$L$ & : 軽液 (側) 昍出流量 & {$[\mathrm{l} / \mathrm{hr}]$} \\
\hline$Q:$ & ：給液流量 & {$[\mathrm{l} / \mathrm{hr}]$} \\
\hline$Q_{C}:$ & ：的界吐出流量 & {$[\mathrm{l} / \mathrm{hr}]$} \\
\hline$a, b$ & $c$ : 常数 & \\
\hline$t \quad:$ & ：溫度 & {$\left[{ }^{\circ} 0\right]$} \\
\hline$\rho_{H}:$ & ：姓出重液比重 & \\
\hline$\rho_{L}:$ & ：昍出撉液比重 & \\
\hline & ：粘性保数 & [c.p \\
\hline
\end{tabular}




\title{
On the Characteristics of the De Laval-type Centrifuge [On the cream separator]
}

\begin{abstract}
Y. Oyama and I. Inoue.
Here the results obtaind from experimental studies on the characteristics of the De Laval-types cream separator are summarized.

In the first experiment with water only, the relationship between water temperatures and outflow rates from discharge lips for lighter and heavier liquids was studied. By this experiment, it was found that the slip of liquid against separating discs increased as the viscosity decreased.

In the second experiment with emulsion containing corn oil in water, the relation between outflow rates of the lighter and heavier liquids was studied with various check ring diameters of the discharge lip for heavier. On this experiment, the following results were obtained. The relation of outflow rates was expressed by $L=a H^{\delta}$, where $L$ and $H$ were outflow rates of the lighter and heavier liquieds respectively, $a$ and $b$ were experimental constants which varied with check ring diameters.

And enlarging of the discharge lip for the lighter liquid or narrowing of the discharge lip for the heavier seemed to be suitable for the cream separator, but for the purpose of enriching the lighter component, enlarging of the discharge lip for the heavier seemed to be preferable.

The thired experiment was conducted with emulsions of water and vegietable oil such as peanut or soybean, including small amount of caustic soda, which were separated into three layers of oil, cream-like matter and water with a test-tube centrifuge. After steady operations of the cream separator, the adherence of the cream-like matter band-likely to the surface of all separating discs was observed, and the band width varied with the feed rate. It was also found that the separating efficiency of the cream separator decreased with the increase of the band width and vice versa. The relations between specific gravities and outflow rates were studied. It was found that among various factors effecting on the separating efficiency, the feed rate was the controlling factor and there was the optimum feed rate in operation.
\end{abstract}

\section{Solutrope}

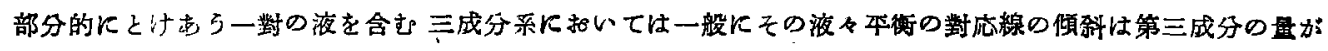

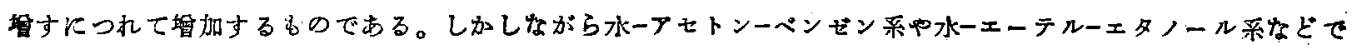

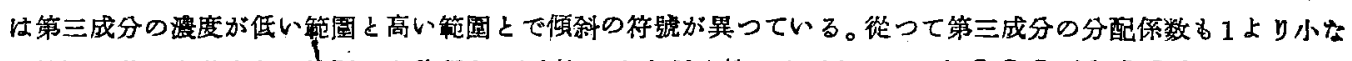

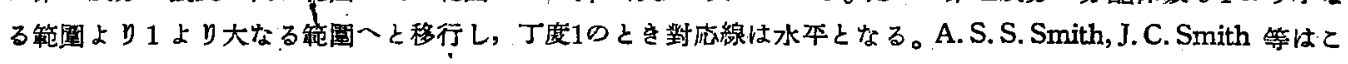
の傾科の附號の反轉のこをを“solutrope”と名付けそのような現像の起る采を“ solutropic system”とよん でいる。これは丁度沸点曲線の傾刹の附號の反轉が起る点を“azeotrope”といい，その上らな現象が起る系を “azeotropic system”をよんでいるのを军似たすので,彼等はてれらの間に一㯖のアナロジーを見出そらとして 努力しているらしい。しかしながら現在までのところでは特别興味ある結畏は得られていないし,及この類似は

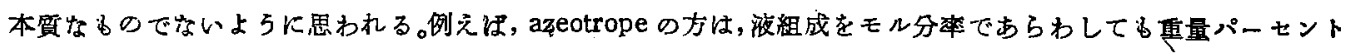

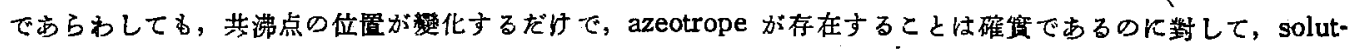
rope の方は, 重量パーセントであらあせ快 solutrope が起るがモル分率であらわすと solutropeがなくなるのが 晋通であることをみてす azeotropeの方が溶液の性質により澡く根ざしているような氣がするのである。とはい

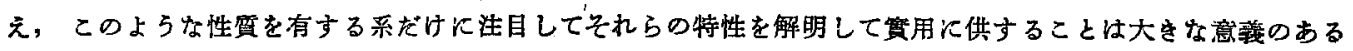
ことは勿論であつて，この最近名前をるらつたばかりの solutrope の成長を新つてゅまない（本田证穗） 